\title{
The Notion of Pedagogical Authority in the Community of Inquiry
}

Peter Paul E. Elicor

\begin{abstract}
This article explores the notion of pedagogical authority as exercised in the Community of Inquiry, the method for facilitating Philosophy for Children (P4C). It argues that the teachers' pedagogical authority in a Community of Inquiry is not predicated on their intellectual superiority or status. Rather it finds its legitimacy in their role as instigators of students' thinking skills, which are assumed to be already possessed by the learners. This thesis is discussed in relation to Rancière's concept of the dissociation of the will and the intellect, which is treated here as conceptual complement to the existing interpretation of pedagogical authority as understood and practiced by scholars in the field of P4C.
\end{abstract}

Keywords: Lipman, Community of Inquiry, Philosophy for Children, pedagogical authority

\section{Introduction}

7 he Community of Inquiry (COI), the pedagogy for teaching Philosophy for Children (P4C), is a process that involves actual philosophizing 1 where students wonder, analyze, exchange ideas, pursue questions, listen to each other, probe assumptions, and think creatively and caringly. For Garrison, the COI provides the "environment for individuals to stretch their depth and breadth of thinking and learning through collaboration." ${ }^{1}$ Its assumption is that learning is essentially an activity of inquiry, and collaborative engagement is essential in nurturing thinking skills. One of its important characteristics is that it is a "shared experience" whereby all members, regardless of age and status, can possibly learn from each other's

${ }^{1}$ D. Randy Garrison, Thinking Collaboratively: Learning in a Community of Inquiry (New York: Routledge, 2016), 55.

(C) 2017 Peter Paul E. Elicor

https://www.kritike.org/journal/issue 21/elicor december2017.pdf

ISSN 1908-7330 
insights. ${ }^{2}$ Thus, the traditional role assigned to the teacher as a purveyor of knowledge is diminished. But, when the COI is contrasted with the traditional classroom setting, differences in the pedagogical relationship between teachers and students become obvious. In particular, one area that requires attention is the pedagogical authority that a teacher is supposed to exercise with the students. This is an important area to consider, for as Pace and Hemmings argue, "the character of teacher-student authority relations has great bearing on the quality of students' educational experience and teachers' work." 3 In the context of a COI, how should "pedagogical authority," we ask, be understood?

This article is divided in four parts. The first part consists of a brief discussion of Philosophy for Children. This is followed by a discussion about the Community of Inquiry and its basic assumptions. The third part brings in Rancière's concept of the dissociation of the intellect and the will, which is treated here as aconceptual complement to the notion of pedagogical authority as understood and practiced by scholars in the field of P4C. Lastly, I explain that the pedagogical authority exercised in a Community of Inquiry necessarily requires the teacher's dissociation of his/her intellect and will.

\section{Matthew Lipman and the Philosophy for Children}

Matthew Lipman's Philosophy for Children, which began in the last quarter of the twentieth century, is one of the notable developments in philosophy and education today. Its conception was inspired by the educational theories of John Dewey, Charles Sanders Pierce, Lev Vygotsky, among many others, which then provided the theoretical foundation for exploring the possibility of teaching philosophy to children, not as a contentladen body of knowledge, but as an activity that, if taught well, nurtures philosophical thinking. According to Lipman, the primary aim of $\mathrm{P} 4 \mathrm{C}$ is to "stimulate children to think carefully, to develop better reasoning and judgments, and to engage in the analysis of some very general but ill-defined concepts." 4 Obviously, this requires a method that is different from the traditional way of teaching philosophy within formal academic settings. Whereas traditional teaching is the "method of handing down knowledge from the teacher to the students," in a COI, the learning agenda is determined

\footnotetext{
${ }^{2}$ Jana Mohr Lone and Michael D. Burroughs, Philosophy in Education: Questioning and Dialogue in Schools (Maryland: Rowman and Littlefield, 2016), 54.

${ }^{3}$ Judith L. Pace and Annette Hemmings, “Understanding Authority in Classrooms: A Review of Theory, Ideology, and Research" in Review of Educational Research, 77:1 (2007), 4.

${ }^{4}$ Matthew Lipman, "What is Happening with P4C?" in Philosophy of Education, vol. 3 of Proceedings of the 20 th World Congress of Philosophy, ed. by David M. Steiner (Ohio: Philosophy Documentation Center, 1999), 22.
}

(c) 2017 Peter Paul E. Elicor https://www.kritike.org/journal/issue 21/elicor december2017.pdf ISSN 1908-7330 
by the students and not by the teacher. ${ }^{5}$ For instance, in a P4C class, students read stories ${ }^{6}$ that are suffused with philosophical ideas from which individual questions are derived. From the questions raised, the students proceed by choosing one particular question to pursue while individually providing reasons for their choice. The students then engage in a collaborative discussion about the ideas and assumptions of the chosen question and its cognate concepts. In this process, a philosophy teacher has to sacrifice the "hermetic terminology" prevalent in philosophical discourses which has unfortunately caused philosophical themes to be obscure to a layperson and "barely intelligible to the undergraduate philosophy major."7

P4C challenges the notion that Philosophy is proper only to adults, philosophy majors, professors, and researchers. As Murris and Haynes note, P4C "calls into question many assumptions about age: it engages children (including very young ones) in kinds of thinking that have traditionally been reserved for adults and it proposes that adults who want to philosophize could benefit by becoming more childlike in their thinking." 8 This is derived from the assumption that the competence for philosophizing is inherently rooted from the basic human propensity to wonder, inquire, and pursue a question - a capacity that does not privilege a certain age, academic degree, or expertise. Consequently, it entails the need to rethink children's capacity for thinking, meaning-making, communicating, and moral-valuing. In this regard, Matthews rightly observes that "a parent or teacher who doesn't hear the questions [of a child or student], or doesn't understand that they are more than, and different from, a mere request for information, misses a chance to do philosophy." ${ }^{\prime \prime}$ It is, therefore, not enough to repackage philosophy and make it intelligible to children for what is equally important is to get adults "recognize that children's questions and concerns are philosophical." 10

\footnotetext{
5 Marella Ada Mancenido-Bolaños, "Philosophy of Education John Dewey's Democracy and Education and the Problem of Education in the Philippines" in Kritike: An Online Journal of Philosophy, 10:2 (2016), 85.

${ }^{6}$ Matthew Lipman has written a number of novels that are utilized to facilitate P4C classes. Other practitioners of P4C use picture books as stimuli for dialogue.

${ }^{7}$ Matthew Lipman, Philosophy Goes to School (Philadelphia: Temple University Press, 1988), 5 .

${ }^{8}$ Joanna Haynes and Karin Murris, "Intra-generational education: Imagining a postage pedagogy" in Educational Philosophy and Theory 49 (2016), 1-2.

${ }^{9}$ Gareth Matthews, The Philosophy of Childhood (London: Harvard University Press, 1994), 39.

${ }^{10}$ Michael J. B. Jackson and Walter H. Ott, "Children and Philosophy: A Comment on Ayim," in Canadian Journal of Education, 5:4 (1980), 104.

(c) 2017 Peter Paul E. Elicor

https://www.kritike.org/journal/issue 21/elicor december2017.pdf

ISSN 1908-7330
}

(c) BY-NC-ND 


\section{The Community of Inquiry (COI) ${ }^{11}$}

There are four (4) basic features that characterize a COI: a) it has an aim, b) it moves where the argument takes it, c) it is dialogical, and d) it fosters varied ways of thinking. ${ }^{12}$ Insofar as the community of inquiry is a group of individuals who share a common purpose of learning, it, therefore, has a direction. Primarily, it aims at producing an output, that is, "some kind of settlement or judgment, however partial and tentative this may be." 13 The procedure involved in a COI is not necessarily preconditioned by a certain trajectory. In other words, the usual process of guiding the students' thinking, which is supposed to lead them to a definitive understanding, is the least of the teacher's worry. Regardless of the source of stimuli and where the discussion may lead, the assumption is that what the students bring to his or her awareness is already meaningful, no matter how insignificant it may seem for others. What stimulates a student's mind, therefore, is treated as a fertile ground for philosophical inquiry.

The role of the teacher, in this context, is not an adjudicator who, after several exchanges of ideas, aborts the flow of discourse and thereby silences the question. Instead, by way of questioning, he or she directs the students to constantly examine the implicit assumptions of their statements, determine the criteria for their answers, provide examples or analogies, and encourage alternative ways of looking at a topic. On this note, Lipman argues that "classroom philosophy teachers are conceived as facilitators of philosophical inquiry rather than as authoritative sources of philosophical knowledge."14 In a COI, teachers create an intellectually nurturing space where students deliberately get involved in their own learning instead of simply relying on what the teacher says. By constantly prodding the students to think critically and reflectively, they become, as a consequence, mindful of the quality of their thinking.

In a COI, the discussion may start from seemingly trivial topics and proceed to ideas that have philosophical implications. In contrast to what Lipman calls "standard paradigm of normal practice," the academic disciplines are wrongfully understood as compartmentalized, exhaustive and

${ }^{11}$ It may be well to note that there are various methods of facilitating P4C within the context of a COI. However, the usual process follows this structure: a) Stimulus, b) Questioning, and c) Dialogue. Lipman's method, in particular, utilizes novels that contain philosophical meanings, which become the point of departure of the dialogue.

${ }^{12}$ See Lipman, Thinking in Education, 83-84.

${ }^{13}$ Ibid., 83.

${ }^{14}$ Matthew Lipman, "The Educational Role of Philosophy (Original Article)," in Philip Cam, "Commentary on Matthew Lipman's 'The Educational Role of Philosophy,'” in Journal of Philosophy in Schools, 1:1 (2014), 12.

(c) 2017 Peter Paul E. Elicor

https://www.kritike.org/journal/issue 21/elicor december2017.pdf

ISSN 1908-7330

(cc) BY-NC-ND 


\section{THE NOTION OF PEDAGOGICAL AUTHORITY}

non-overlapping. ${ }^{15}$ For instance, the empirical sciences do not usually cross boundaries into religious studies or the humanities. If the goal of education is to teach students how to think well, Lipman writes, this means "giving students practice in reasoning, through classroom discussion involving concepts that reach across all the disciplines rather than only those that are specialized within each subject."16 It must be noted, however, that this does neither require a teacher to have a prior knowledge of everything nor does $\mathrm{s} /$ he need to feign mastery. On the contrary, a teacher should genuinely immerse in the process of inquiry without restraining its flow and direction according to the confines of his/her expertise. According to Kohan,

a nice image that a teacher can offer is one who thinks with others-no matter what her age, race or gender might be; who stages and promotes and facilitates experiences of thinking; who has no models and promotes no models; who offers others something to think about; who does not obstruct the road of his or her students; who propitiates encounters that she cannot herself advance or foresee. ${ }^{17}$

But, one may ask, what is the difference between the dialogue that happens in a COI from a "nice conversation"? In contrast with conversation, dialogue does not aim at arriving at a consensus where, Lipman writes, "personal note is strong but the logical thread is weak."18 Rather, in a dialogue, instability in the actual flow of arguments is actually important because such will implicitly move its course to branch off to other equally valid points of view. In other words, the dialogical exchange in a COI does not always presuppose a harmonious sharing of thoughts. It is rather naïve to think that the goal of the COI is simply to get one's thoughts recognized and emotions satisfied. On the contrary, putting forward one's ideas for examination and testing could be intellectually challenging and emotionally disturbing. However, it must be noted that this is based on the assumption that in order to efficiently exercise and develop thinking, one has to collaboratively engage in a dialogue within a non-hostile environment whereby a variety of arguments, including dissenting ideas, are acknowledged. In other words, the community's emphasis on inquiry and

\footnotetext{
${ }^{15}$ See Lipman, Thinking in Education, 18.

16 Matthew Lipman and Ron Brandt, “On Philosophy in the Curriculum: A Conversation with Matthew Lipman," in Educational Leadership, $46: 1$ (1988), 34.

17 Walter Omar Kohan, Philosophy and Childhood: Critical Perspectives and Affirmative Practices (New York: Palgrave MacMillan, 2014), 40.

${ }^{18}$ Ibid., 87.

(c) 2017 Peter Paul E. Elicor

https://www.kritike.org/journal/issue 21/elicor december2017.pdf

ISSN 1908-7330
}

(cc) BY-NC-ND 
rational deliberation do not necessarily lead to hostility against each other's thoughts and feelings as a result of unavoidable disparities. On the contrary, since everyone knows that s/he could be "wrong" in his/her ideas, a certain degree of understanding and tolerance will develop. On this note, Lipman stresses that the community of inquiry

is not a community of solidarity where everybody feels the same and has the same ideas and sensations and so forth, but [a kind of community] where there's a division of feeling; there's a complimentary of feeling and of thinking. So they rely on each other, depend on each other. It's very much like a team where there are certain people who are good at passing and other good at running. And they depend on each other; they know they can count on each other. ${ }^{19}$

By and large, P4C has at its core the idea and practice of turning ordinary classrooms into vibrant communities of inquiry where students are empowered to engage in a philosophical discussion with other students under the facilitation of a teacher-philosopher. The primacy of dialogue among equal co-inquirers in a COI democratizes the basic capacity of both students and teachers for thinking, speaking and listening; and likewise, being spoken to and being listened to.

In the next section, I will discuss Jacques Rancière's concept of the dissociation of the intellect and Wwill, which, I think, can function as a conceptual complement in understanding the pedagogical authority a teacher should exercise within the context of a COI.

\section{Jacotot's Intellectual Adventure}

In his book, The Ignorant Schoolmaster: Five Lessons of Intellectual Emancipation, Rancière recounts the "intellectual adventure" of Joseph Jacotot who, while teaching in Louvain, encountered several Flemish students who wanted to enroll in his class. Such would not have posed any problem if Jacotot himself could speak Flemish. Unfortunately, he could not, and these new students did not know how to speak French either. Nevertheless, sensing a learning opportunity, he took the challenge of teaching a language he could neither speak nor understand. The language rift did not deter the adventurous Jacotot from admitting these students in his class. Any practical

${ }^{19}$ Matthew Lipman, "Philosophy for Children," YouTube video, 56:00, 29 March 2010, $<$ https://www.youtube.com/watch?v=Lp-81I8h7gg>.

(c) 2017 Peter Paul E. Elicor

https://www.kritike.org/journal/issue 21/elicor december2017.pdf

ISSN 1908-7330 
teacher, being placed under such circumstance, would perhaps have chosen to find a translator or interpreter to bridge the language gap and therefore facilitate a mediated instruction. Jacotot, however, found another way. Totally unprecedented, he gave each student a bilingual edition of Fenelon's Telemaque, that includes both French and Flemish versions. In the entire course, he sought a way to command these students to learn the French version by means of comparing and contrasting it against the language they could understand. In Jacotot's account, after the students understood the first half of the book, he commanded them to repeat over and over until they could actually read and understand the French version. And much to Jacotot's surprise, after a certain period of time, the students actually began to speak and write in French without the help of a textbook, much less his own area of professional expertise.

From this pivotal experience, Rancière thinks that Jacotot created a "scandal" in the early nineteenth-century system of education by claiming that an "ignoramus could teach another what he himself did not know, asserting the equality of intelligence and opposing intellectual emancipation to popular instruction." 20 Prior to this experience, what Jacotot believed was that the role of a teacher is to guide young and uninitiated minds to an unchartered body of knowledge through his mastery and expertise. And like most critical teachers, Jacotot did not subscribe to the common notion that a teacher' job is simply to bombard students with information and to regurgitate them as a basis for evaluation. Rather, he believed that a student needs the constant guidance-hence, explication-of a knowledgeable teacher because of the assumption that a novice mind might get lost in the unfamiliar terrain of knowledge, possibly mistaking the right path from the unnecessary detours, the essential from the unnecessary, the truth from the untruth. Such possibility, in Jacotot's un-emancipated mind, warrants his valuable explanations whenever necessary, which also assumes his mastery over the subject under discussion. However, this conviction was challenged, if not shattered, by the very experience he had with the Flemish students. How could he, an individual who did not have the practical knowledge of the Flemish language, have caused the transformation of these students from being non-speakers of French to actual fluent users of the language?

\section{Dissociation of the Intellect and Will}

Inferring from Jacotot's intellectual adventure, Rancière argues that education is never simply a transmission of knowledge, information or skills

${ }^{20}$ Jacques Rancière, The Emancipated Spectator, trans. by Gregory Elliot (London: Verso, 2011), 1 .

(C) 2017 Peter Paul E. Elicor

https://www.kritike.org/journal/issue 21/elicor december2017.pdf

ISSN 1908-7330

(c) BY-NC-ND 
from a master to a student. Oftentimes, education is wrongfully understood simply as a practice of indoctrination whereby the student abandons his/her intellectual autonomy to the master, who is assumed to be a source of reliable knowledge. In Rancière's parlance, "pedagogical logic" refers to the traditional ways of educating, whereby a teacher is considered a "master" whose explications are essential in the educational journey of the students who, at the onset, are considered "ignorant." In this sense, a promise of equality between the teacher and the student is implicitly presupposed to be a goal in the process of the educational transaction. Such promise of equality, however, never comes to fruition because the kind of authority assumed by a teacher in the pedagogical logic always eludes any attempt of equalizing its position with that of the student.

Moreover, the usual method behind almost all forms of educational practice is that of explication. What all conscientious professors believe is that "the important business of the master is to transmit his knowledge to his students so as to bring them, by degrees, to his own level of expertise." 21 In other words, these well-meaning teachers think that their profession is to bring the students from the state of ignorance to enlightenment, from unfamiliarity to understanding, from stupidity to intelligence. Consequently, their assumed role involves the reduction, if not abolishment, of the distance between his/her adequate knowledge and the incompetence of the learner. However, if one were to examine the effects of such method, it actually breeds a very subtle type of intellectual subjugation-a stultification-whereby a student, after being immersed in this kind of pedagogy, will only understands one thing, that is, understanding can happen only by explication. In effect, this kind of pedagogical method perpetuates the practice of absorbing data rather than critical thinking, submission rather than emancipation. Students, therefore, are stultified not simply because of a particular procedure, but by an "explicatory order that tells them that they can't do it by themselves ... and that the master is the required condition of their learning." 22

Thus, for Rancière, education is not measured on the basis of how much knowledge the student "absorbs" from the teacher. On this note, Kohan believes that "there is no entrainment between teaching and learning"; that is, it is not a guarantee that "if someone teaches, another learns; and that if someone learns it is because another taught her." 23 In other words, teaching is not predicated on the relationship between one's intelligence and the intelligence of another, but on the relationship between one's will and the will

\footnotetext{
${ }^{21} \mathrm{Ibid} ., 3$.

22 Richard Stamp, "Of Slumdogs and Schoolmasters: Jacotot, Rancière and Mitra on self-organized learning," in Educational Philosophy and Theory 45:6 (2013), 653.

${ }^{23}$ Kohan, Philosophy and Childhood, 39.
}

(c) 2017 Peter Paul E. Elicor https://www.kritike.org/journal/issue 21/elicor december2017.pdf ISSN 1908-7330 
of another. It is, therefore, constitutive of the teacher's act of obliging the will of the student to exercise its own rational powers regardless of the teacher's actual possession or mastery of knowledge. The dissociation between the intelligences and will is practically the reason why Jacotot's teaching experiment worked. Indeed, the possibility of knowing and learning, despite the teacher's lack of mastery and knowledge, will only make sense when driving a student's will becomes the primary goal in the entire process of education. ${ }^{24}$

\section{Pedagogical Authority in the Community of Inquiry}

P4C and COI redefine the notion of pedagogical authority and bring to light the importance of equality in the pedagogical relationship between teachers and students. The COI aborts the teacher's traditional role as a knowledge-provider, which unfortunately in some cases, causes intellectual passivity and stunts intellectual growth. In a COI, a teacher is a part of the entire process of inquiry. She does not "stand" outside the community. Thus, her role is as important and integral as that of the students. But the COI does not abolish the authority of teachers. It is not anti-authoritarian. On the contrary, it seeks to maintain the teachers' role of obliging the students to think for themselves. In other words, the transformation of traditional classroom environment to communities of inquiry does not entail the leveling off of the status of teachers and students. According to Lipman:

In the normal course of philosophical inquiry, such as in a classroom dialogue, the teacher may be presumed to possess authority with regard to the techniques and procedures by which such inquiry is to be prosecuted. It is the teacher's responsibility to assure that proper procedures are being followed. But with respect to the give-and-take of philosophical discussion, the teacher must be open to the variety of views implicit among the students. ${ }^{25}$

${ }^{24}$ In ordinary circumstances, this is actually a very common experience that children get from their parents. Oftentimes, the parents who constantly remind their children to study, learn, do their assignments, and commit to their studies do not actually know, much less master, what their children are supposed to learn. A mother, for instance, does not need to have a prior expertise on a subject, say chemistry, before she can oblige her child to learn it. In other words, the obligation she imposes on her child does not necessitate her to have a pre-knowledge of it. The will to move another person's will, therefore for Rancière, is independent from what the latter is actually moved to do, learn and acquire.

${ }^{25}$ Matthew Lipman, Ann Margaret Sharp, and Frederick Oscanyan. Philosophy in the Classroom, $2^{\text {nd }}$ ed. (Philadelphia: Temple University Press, 1980), 45.

(c) 2017 Peter Paul E. Elicor

https://www.kritike.org/journal/issue 21/elicor december2017.pdf

ISSN 1908-7330

(c) BY-NC-ND 
Teachers' authority is maintained on the basis of their knowledge of the techniques and procedures that philosophical inquiry abides by. It is incumbent upon the teacher to make sure that the students preserve and maintain the values of collaborative inquiry, dialogue, and the varied ways of thinking. ${ }^{26}$ Thus, teachers are not supposed to terminate the progression of inquiry and exchange of ideas by imposing their own knowledge and demonstrating mastery on a topic. Instead of pre-empting the joy of wonderment and discovery (no matter how these may seem trivial to an adult), teachers are to encourage students to pursue more questions, constructively challenge others' position while being mindful of their own tacit assumptions, careful not to assume knowing the entire truth. In this regard, Lone and Burroughs assert that in a COI, there is a "consensus of 'epistemological modesty': an acknowledgment that all members of the group, including the facilitator, are fallible, and therefore hold views that could end up being mistaken," 27 This is where a teacher's dissociation of his/her intellect and will becomes obvious. It is not important whether his/her intelligence is recognized by the class, for what is more essential is his/her capacity to drive the students' will to think for themselves. As co-inquirers, Murris asserts that teachers should ask questions that "provoke philosophical enquiry, without knowing the answers to the questions s/he poses; and facilitating only where appropriate, that is, benefitting the community's construction of new ideas." 28 Thus, to deprive the students from exploring by themselves the richness of their imaginations, insights, and experiences is no less than to deny them of their inherent capacity to think independently even within the context of a community.

Therefore, to recognize a sense of epistemic equality between the teacher and students does not, in any way, diminish the former's pedagogical authority. Teachers hold a position that is equally important as the position of the students. A teacher's dissociation between his/her intellect and will provides the condition for the possibility of teaching without stultifying, that is, facilitating learning by supposing equality at the very beginning. Needless to say, COI will inevitably fall short from its objectives once educators fail at the outset to treat students from a position of epistemic equality and continue to acknowledge it as the course progresses. It is for this reason that the COI, I think, ultimately draws its critical potential from the recognition of epistemic equality, which also reconfigures the pedagogical authority of teachers.

\footnotetext{
${ }^{26}$ Thinking for Lipman is not only "critical thinking" but it also means "caring thinking" and "creative thinking."

${ }^{27}$ Jana Mohr Lone and Michael D. Burroughs, Philosophy in Education, 55

${ }^{28}$ Karin Murris, The Posthuman Child: Educational Transformation through Philosophy with Picturebooks (New York: Routledge, 2016), 182.
}

(c) 2017 Peter Paul E. Elicor https://www.kritike.org/journal/issue 21/elicor december2017.pdf ISSN 1908-7330 


\section{0}

THE NOTION OF PEDAGOGICAL AUTHORITY

Moreover, teachers who utilize COI as a pedagogy cannot exercise a hierarchical relation between their intelligence and that of the students. This means that their authority has to concretely manifest in their exercise of a horizontal (not top-down) pedagogical relation between their will and the will of the students. I follow here Mulloly who articulates that the definition of pedagogical authority should "not be approached as the property of a position or person that others must accept," but rather as "a property of an interaction, constituted by the active work of all involved, regardless of the position they may display." 29 Thus, teachers should avoid the mistake of thinking that the significance of their role is based on their intellectual superiority, because the legitimacy of their pedagogical authority holds only insofar as they instigate the students' thinking skills which are assumed to be inherently possessed by the students.

Lastly, a teacher handling a P4C class must be open to an intellectual journey with the community that may possibly lead to conceptual highways, detours, stop-overs, and alleys. At one point, s/he may be in a position of an interlocutor; at another point, in a position of a student who willfully allows him/herself be taught; or in most cases, in a position of a concerned cojourneyer who constantly prods the students to dig deeper. In such intellectual adventure, it may be well to realize that no teacher solely steers the wheel. One of the ultimate goals of the COI, therefore, is never to lead a student to the false notion that a teacher's role is indispensable in the process of education, but rather to make a student realize that s/he actually holds the reins of his/her education. In this regard, Canuto asserts that what the COI calls for "is a teacher who is ready to relinquish ultimate control of the student's path of discovery and who can put faith into young children's ability to grapple with abstract concepts." 30 By letting students take responsibility for their learning, they can claim intellectual independence that empowers them to overcome the limits of the traditional pedagogical methods.

\section{Conclusion}

The assumptions of the COI destroy the intellectual hierarchy presupposed in traditional classroom settings. The COI, especially its

\footnotetext{
${ }^{29}$ James Mullooly, "Playing with Pedagogical Authority" in Classroom Authority: Theory, Research, and Practice, ed. by Judith L. Pace and Annette Hemmings (New Jersey: Lawrence Erlbaum Associates, Inc., 2006), 62.

30 Abigail Thea Canuto, "Reflections on Theory and Pedagogy of Challenges in Facilitating Children's Dialogues in the Community of Inquiry" in International Journal of Whole Schooling 11:1 (2015), 10.
}

(c) 2017 Peter Paul E. Elicor

https://www.kritike.org/journal/issue 21/elicor december2017.pdf

ISSN 1908-7330

(c) BY-NC-ND 
insistence on dialogue, positions all members on an equal footing in terms of collaboratively pursuing questions and sharing insights. This redefines the teacher's role from a position that holds the explicative and evaluative powers to a position of a co-inquirer. In other words, the COI reconfigures the traditional understanding of pedagogical authority from a teacher-know-itall to a philosopher-facilitator. This paper has argued that such can be achieved by the dissociation of the intellect and will. It entails a transformation of the idea of authority that is progressively aligned to the values of collaboration, assistance, and journeying. It is for this reason that the understanding of the role of teachers in the context of a COI includes: collaborators, co-pilgrims, and co-learners. Finally, thinking and learning never occur in isolation. By thinking within the COI, both students and teachers make more sense of their individual experiences in the process of letting their dearly-held ideas open for critique. This basically requires a teacher who can sustain a thoughtful dialogue that proceeds from a process of deliberative, collaborative and meaningful interaction with the students.

Department of Philosophy, Ateneo de Davao University, Philippines The Graduate School, University of Santo Tomas, Philippines

\section{References}

Canuto, Abigail Thea, "Reflections on Theory and Pedagogy of Challenges in Facilitating Children's Dialogues in the Community of Inquiry" in International Journal of Whole Schooling 11:1 (2015).

Garrison, D. Randy, Thinking Collaboratively: Learning in a Community of Inquiry (New York: Routledge, 2016).

Jackson, Michael and Walter H. Ott, "Children and Philosophy: A Comment on Ayim," in Canadian Journal of Education 5:4 (1980).

Joanna Haynes \& Karin Murris, "Intra-generational education: Imagining a post-age pedagogy" in Educational Philosophy and Theory 49 (2016).

Kohan, Walter Omar, Philosophy and Childhood: Critical Perspectives and Affirmative Practices (New York: Palgrave MacMillan, 2014).

Lipman, Matthew, "Philosophy for Children," YouTube video, 56:00, 29 March 2010, <https://www.youtube.com/watch?v=Lp-8118h7gg >. Philosophy Goes to School (Philadelphia: Temple University Press, 1988).

"The Educational Role of Philosophy (Original Article)," in Philip Cam, "Commentary on Matthew Lipman's 'The Educational Role of Philosophy,'" in Journal of Philosophy in Schools, 1:1 (2014)

Thinking in Education $2^{\text {nd }}$ ed. (New York: Cambridge University

Press, 2003).

(c) 2017 Peter Paul E. Elicor

https://www.kritike.org/journal/issue 21/elicor december2017.pdf

ISSN 1908-7330

(cc) BY-NC-ND 


\section{THE NOTION OF PEDAGOGICAL AUTHORITY}

"What is Happening with P4C?" in Philosophy of Education, vol. 3 of Proceedings of the 20 $0^{\text {th }}$ World Congress of Philosophy, ed. by David M. Steiner (Ohio: Philosophy Documentation Center, 1999

Lipman, Matthew and Ron Brandt, "On Philosophy in the Curriculum: A Conversation with Matthew Lipman," in Educational Leadership, 46:1 (1988).

Lipman, Matthew, Ann Margaret Sharp, and Frederick Oscanyan, Philosophy in the Classroom, $2^{\text {nd }}$ ed. (Philadelphia: Temple University Press, 1980).

Lone, Jana Mohr and Michael D. Burroughs, Philosophy in Education: Questioning and Dialogue in Schools (Maryland: Rowman and Littlefield, 2016).

Mancenido-Bolaños, Marella Ada, "Philosophy of Education John Dewey's Democracy and Education and the Problem of Education in the Philippines" in Kritike: An Online Journal of Philosophy 10:2 (2016).

Matthews, Gareth, The Philosophy of Childhood (London: Harvard University Press, 1994).

Mullooly, James, "Playing with Pedagogical Authority" in Classroom Authority: Theory, Research, and Practice, ed. by Judith L. Pace and Annette Hemmings (New Jersey: Lawrence Erlbaum Associates, Inc., 2006).

Murris, Karin, The Posthuman Child: Educational Transformation through Philosophy with Picturebooks (New York: Routledge, 2016).

Pace, Judith L. and Annette Hemmings, "Understanding Authority in Classrooms: A Review of Theory, Ideology, and Research" in Review of Educational Research 77:1 (2007).

Rancière, Jacques, The Emancipated Spectator, trans. Gregory Elliot (London: Verso, 2011).

The Ignorant Schoolmaster, Five Lessons in Intellectual Emancipation, trans. by Kristin Ross (California: Stanford University Press, 1991).

Stamp, Richard, "Of Slumdogs and Schoolmasters: Jacotot, Rancière and Mitra on self-organized learning," in Educational Philosophy amd Theory 45:6 (2013). 